\title{
Reply to the comment on "Effects in North Africa of the 934-940 CE Eldgjá and 1783-1784 CE Laki eruptions (Iceland) revealed by previously unrecognized written sources"
}

\author{
Vermondo Brugnatelli ${ }^{1}$ - Alessandro Tibaldi ${ }^{1}$ (D)
}

Received: 20 May 2021 / Accepted: 1 July 2021 / Published online: 31 July 2021

(C) The Author(s) 2021

We are grateful to our colleagues Newfield and Oppenheimer for the complement of information they provide. In our article Brugnatelli and Tibaldi (2020), we did not enter into all the details concerning the already known sources, since they have already been dealt with by, among others, both of them, as one can see in the text and in the references. We limited ourselves to point out that some of the examined "witness statements" are not as straightforward as one could expect, either concerning the dating of the events recorded or their description. In the following remarks, we will deal more thoroughly with the sources commented on by Newfield and Oppenheimer.

1. As we have pointed out, the pieces of information contained in the Chronicum Scotorum are not explicitly provided with dates, but are placed in a sequence of years, so that appointing the year $939 \mathrm{CE}$ (a dating that we have not challenged) required a long and thorough philologic work (the "careful scholarship" referred to by Newfield and Oppenheimer: the three most significant studies were quoted by ourselves in the original article). The erroneous date assessed by the Annals of Clonmacnoise has been evoked precisely as an example of the difficulties that arise in understanding this source.

2. Analogously, Widukind's Res Gestae Saxonicae provides information difficult to decode, both concerning the date and the nature of the phenomenon recorded. As we have pointed out, a literal reading of the text leads to believe that the anomalous darkening of the sun took place before $936 \mathrm{CE}$. Only a comparison with other sources relating events associated with the death of King

Editorial responsibility: M.H. Ort.

Alessandro Tibaldi

alessandro.tibaldi@unimib.it

1 University of Milan Bicocca, Milan, Italy
Henry I permits the guess that this episode might have happened shortly after that date. In any case, the report itself does not permit the event's precise assignment to $939 \mathrm{CE}$, a date that is ultimately inferred from the testimony of the Chronicum Scotorum.

Also, the description is not conclusive as to the phenomenon itself. We will briefly recall here two main issues, namely the "colour" of the solar light and the lack of clouds.

The reddish blood-like colour is explicitly attributed to the sun itself by the Chronicum Scotorum alone ("forsan ngrein", literally "on the sun"), while the description by Widukind specifically assigns this colour to the effect the weak light of sun assumed inside the houses after passing through the windows ("intrinsecus autem per fenestras domorum rubeus tamquam sanguis"). The use of autem, "however, on the other hand", points to a difference between the simple lack of brightness ("splendor pene nullus") perceived outdoors ("forinsecus") and the reddish colour within the houses. Interestingly, this difference matches an optic phenomenon, studied and described in detail by Gedzelman (1975), namely that "the sky near the horizon is redder during an eclipse", while "during an eclipse the blueness of the zenith is enhanced". Given that the light does not enter the houses from the zenith, but from an angle nearer to the horizon, this could explain the redness observed indoors but not outdoors.

Concerning the lack of clouds (absque nubilo), Newfield and Oppenheimer state that "the middle-atmosphere veiling associated with volcanic sulfate aerosols is unlikely to have been confused with common cloud cover". However, the phenomenon recorded in Morocco was remarkably associated with "clouds" (ghamam), to the point that the year was named "the year of the clouds". Of course, it is possible that the phenomenon was perceived differently at a different latitude, but the Moroccan testimony makes it doubtful. Moreover, it should be noted that the lack of clouds 
is also associated with eclipses elsewhere. For instance, a lunar eclipse recorded in the Annales Casinates was thus described: "MXLII Indictione VII. Hoc Anno 6 die Jan. obscurata est Luna per horas quinque cum esset decima tertia, \& facta est tota sanguinea; \& cum inciperet quasi aurora, rediit lumen illius ex illa parte, unde copit obscurari, quasi esset XXVIII \& sic obiit; et non videbatur nubes in Ceelo" (1042, 7th indiction [recte 10th]). This year, on Jan. 6th [recte 9th], the moon was darkened (obscurata est) during five hours when it was at the 13th (day of the lunar month, i.e. around full moon) and it became all bloody (tota sanguinea), and when dawn was almost beginning, its light came back from the same part where it had begun to darken, like it were at the 28th (day of the lunar month, i.e. the last visible crescent before the new moon) and in this condition it set, and no cloud was visible in the sky (non videbatur nubes in Coelo) [it refers to the total lunar eclipse of January 9th, 1042 AD, see moonblink.info/Eclipse/eclipse/1042_01_09].

In regard to the statement of Newfield and Oppenheimer that we "misleadingly fix the Eldgja eruption to 934-940 CE", this allegation is based on a biased reading of the title of our paper that names the eruption with allusion to the time-span mostly mentioned and discussed in the scientific community. The abstract placed at the beginning clearly informs the reader that our paper deals with "two catastrophic fissure eruptions (...) known as Eldgjá eruption (934-940 CE) and Laki eruption (1783-1784 CE)" and announces that previously unrecognized written sources "report events in Morocco in the time period October 938-October $939 \mathrm{CE}$, and in Tunisia in the year 1783 CE. These data can be helpful in dating and determining the area of influence of the eruptions". In the body of our paper, we emphasized that Oppenheimer et al. (2018) bracketed the beginning of the event at the spring of $939 \mathrm{CE}$, but we also briefly summarized previous studies by other authors who proposed a different inception age. More in detail, these studies considered above all acidity, conductivity and basaltic glass shards found in the GISP2 Greenland ice core, combined with tree-ring records from northern Europe. Hammer et al. (1980) proposed $934 \pm 2 \mathrm{CE}$, Zielinski et al. (1995) suggested $938 \pm 4 \mathrm{CE}$, and Vinther et al. (2006) indicated $933 \pm 1 \mathrm{CE}$. As we already summarized in Brugnatelli and Tibaldi (2020), several data indicate that most of the eruption effects have an age of $939 \mathrm{CE}$, such as the contemporary observation of a blood-red sun as recorded in an Irish chronicle, indicative of volcanic haze (McCarthy and Breen 1997), Greenland ice core records (Sigl et al. 2015), historical accounts of astronomical and meteorological phenomena (Stothers 1998; Fei and Zhou 2006), and environmental data (Oman et al. 2006; Baillie and McAneney 2015), with a prolongation of the eruption in $940 \mathrm{CE}$ as emerging from tree-ring analyses that indicate a pronounced northern hemisphere summer cooling in that year (Stoffel et al. 2015). In
Brugnatelli and Tibaldi (2020), we clearly stated that our own analyses of the historical chronicles indicate the year $939 \mathrm{CE}$ as the one with most reports of phenomena attributable to the Eldgjá eruption, and at one point we wrote "... allows us to confirm 939 CE as the date of the Eldgja eruption".

3. Coming now to consider the Annales Casinates, the hypothesis that the passage we quoted is a "two parter" is far from established: it is just a guess, put forward by Sigl et al. (2015) supplement material because the description in the second part "possesses many hallmarks of a volcanic dust-veil". Indeed, this circumstance cannot be excluded, but it seems unlikely. Both the initial and the final parts point to an eclipse. The beginning specifies date, time and duration, which coincide with the solar eclipse of 19 July 939 CE. The allusion to the halved sun we find at the end of the annotation is also a clear hallmark of an eclipse. The description of a different phenomenon, if any, would reside in the middle of the statement, namely "Aspiciebamus nos Solem, \& non habebat ullam fortitudinem, nec ad splendorem nec ad colorem. Videbamus vero Coelum, \& mutatus erat color illius tamquam lividus, \& alii dixerunt ut viderent Solem tamquam dimidium" ("We looked at the Sun, and it had no strength either for brightness or for colour. Indeed, we saw the Sky, but its colour was altered, somehow leaden, and some people said that they saw the Sun almost halved"). The appearance, here, of the pronoun nos (which would be superfluous in a plain sentence, given that Latin is a pro-drop language) highlights the first person in order to contrast what the authors of the annotations (the monks) saw and what was reported to them from other sources, namely the alii: "WE looked at the Sun.. WE saw the Sky... OTHERS told that THEY saw...". The sentence seems conceived as a whole, rather than being made up of two different utterances.

4. As we reported in our article and Newfield and Oppenheimer underline, Foresti's Supplementum chronicarum was first published in Venice in the year 1483. The original text is in Latin, but it was translated to Italian quite early. We quoted the Italian version from an edition of 1535 , which reproduces the translation originally made by Francesco Cei, written in 1488 in Florence and published for the first time in Venice in 1491 (see colophon in the References). The 1535 edition is somewhat enlarged and updated, but the passage under scrutiny is basically the same in the Latin and in the Italian versions. On the basis of the comparison of this text with Widukind and several other chronicles that repeated and possibly abridged Widukind, Newfield and Oppenheimer consider that Foresti too drew from this tradition. Admittedly, a link with the sources they recall 
seems quite probable, yet a straightforward derivation cannot be established, as far as we know. Two details not encountered elsewhere seem original and deserve attention, since they might be the hint of the conflation of material coming from other unattested sources: the specification of a time-span for the phenomenon (1483, Latin: per aliquot dies; 1491, Italian: per alchun giorno) and the specific mention of Venice as a place where many people died after the phenomenon (apud Venetias quammaxime etiam alibi). The duration was not specified in Widukind's - nor in the other chronicles derived from it - but it is an important detail, because the fact that the bloody sun lasted some days would rule out an eclipse. It seems as though a fragment of a local Venetian chronicle has been inserted here, sandwiched within a list of popes taken from other sources providing information on people and events of greater importance (kings, emperors, popes). A linguistic clue supports this hypothesis, namely the genitive memoriae accompanying the adjective dignus "worth remembering" in the description of a Venetian Doge (the same construction of Italian degno di...), vs. the ablative memoria used in the pieces of information about the popes that precede and follow the Venetian insertion:

$$
\begin{aligned}
& \text { Foresti (1483 p. 93-94): Leo septimus papa } \\
& \text { (...) nil memoria dignum post se reliquit } \\
& \text { Petrus Ursi particiati filius (...) de quo etiam nil } \\
& \text { memorie dignum habere potuimus Stephanus } \\
& \text { octavus papa (...) ut nil memoria dignum ab eo } \\
& \text { geri potuerit }
\end{aligned}
$$

As to the location, the way Venice is alluded to does not seem a simple re-localisation, but rather an addition to what has been reported in other sources: "above all (quam maxime) in the surroundings of Venice (apud Venetias) as well as elsewhere (etiam alibi)".

Admittedly, these considerations are tenuous clues, but they are worth deeper philological research for a confirmation or denial, and that is the reason why we have included it in our article.

5. We agree with Newfield and Oppenheimer that "the more contemporary the source is to the eruption generally the better", but we do not share the distrust Newfield and Oppenheimer show with regard to the well-known Arabic chronicle Rawd al-Qirtās, whose only shortcoming is its being achieved in the early fourteenth century, some centuries after the eruption. However, besides the time of composition, the content itself must be taken into consideration. Despite some inaccuracies noted by historians, mostly regarding events of later dynasties, Rawd al-Qirtās remains an important source for the history of northern Africa in the early centuries of Islamic rule. As far as we know, the ultimate source of the witness we quoted is not known, but the accurate details concerning date and description of the phenomenon make it unlikely that it is a forgery. From it, we get a confirmation concerning the date of $939 \mathrm{CE}$, one already obtained through the study of sources already known. Moreover, it documents that the extension of the phenomenon reached southwards as far as Morocco, where heavy consequences lasted several days. No matter how uncertain the ultimate source of this witness might be, we consider it an important element to take into consideration for further researches.

Summing up, we believe that we have now provided the reader with the necessary insights to evaluate in a balanced way the greater or lesser reliability of the sources and the greater or lesser accuracy of the events they report, and we are pleased to observe that the new materials produced in our article fully confirm the acquisitions reached with a patient philological and historical work on the sources existing up to now.

Acknowledgements We are grateful to the Associate Editor Michael Ort for his helpful suggestions on a previous version of the manuscript.

Funding Open access funding provided by Università degli Studi di Milano - Bicocca within the CRUI-CARE Agreement.

Open Access This article is licensed under a Creative Commons Attribution 4.0 International License, which permits use, sharing, adaptation, distribution and reproduction in any medium or format, as long as you give appropriate credit to the original author(s) and the source, provide a link to the Creative Commons licence, and indicate if changes were made. The images or other third party material in this article are included in the article's Creative Commons licence, unless indicated otherwise in a credit line to the material. If material is not included in the article's Creative Commons licence and your intended use is not permitted by statutory regulation or exceeds the permitted use, you will need to obtain permission directly from the copyright holder. To view a copy of this licence, visit http://creativecommons.org/licenses/by/4.0/.

\section{References}

Baillie MGL, McAneney J (2015) Tree ring effects and ice core acidities clarify the volcanic record of the first millennium. Clim past 11:105-114. https://doi.org/10.5194/cp-11-105-2015

Brugnatelli V, Tibaldi A (2020) Effects in North Africa of the 934-940 CE Eldgjá and 1783-1784 CE Laki eruptions (Iceland) revealed by previously unrecognized written sources. Bull Volcanol 82(11):1-14

Fei J, Zhou J (2006) The possible climatic impact in China of Iceland's Eldgjá eruption inferred from historical sources. Clim Chang 76:443-457. https://doi.org/10.1007/s10584-005-9012-3

Foresti JPh (1483) Jacobus philippus Bergomensis, Supplementum chronicarum orbis ab initio mundi usque ad annum 1482 - in 
inclita Venetiarum civitate, per Bernardinum de Benaliis Bergomensem, die 23 Augusti 1483

Foresti Jph (1491) Jacobo Filippo da Bergamo (Foresti), Supplementum chronicarum (Italian version). - Impresso nella inclita citta de Venetia: per me Bernardino Rizo de Novara, lanno de la nostra salute 1491 adi 8 de Octobrio regnante lo inclito Principe Agustino Barbarico. Colophon: "Finisce adunque el presente volume diviso in libri 15, chiamato Supplemento de Chroniche, compilato in latino da frate Jacobo Filippo da Bergamo del ordine de sancto Agustino Theologo prestantissimo, et vulgarizato per me Francesco C. nella nobilissima citta de Fiorenza questo anno nel 1488 et finito adi 17 de Zenaro nel prefato millesimo a laude honore exaltatione et gloria de la individua \& sancta Trinitade padre figliolo \& spirito sancto (...) Ho seguitato nel volgare tutto l ordine del primo auctore latino benche agionto da me ho qualche cossa \& levata secondo che al basso mio ingegno necessario e paruto."

Foresti JPh (1535) Supplementi delle croniche del venerando Padre Frate Jacobo Philippo, dell'ordine Heremitano, primo auttore. Novamente rivisto, vulgarizato, et con somma diligentia corretto. Con la gionta del MDXXIIII insino al MDXXXV. Impresso Venetii per Bernardino Bindone

Gedzelman SD (1975) Sky color near the horizon during a total solar eclipse. Appl Opt 14(12):2831-2837

Hammer CU, Clausen HB, Dansgaard W (1980) Greenland ice sheet evidence of postglacial volcanism and its climatic impact. Nature 288:230-235

McCarthy DP, Breen A (1997) An evaluation of astronomical observations in the Irish annals. Vistas Astron 41(1):117-138

Oman L, Robock A, Stenchikov GL, Thordarson T (2006) High-latitude eruptions cast shadow over the African monsoon and the flow of the Nile. Geophys Res Lett 33:L18711. https://doi.org/ 10.1029/2006GL027665

Oppenheimer C, Orchard A, Stoffel M, Newfield TP, Guillet S, Corona C, Sigl M, Di Cosmo N, Büntgen U (2018) The Eldgjá eruption: timing, long-range impacts and influence on the Christianisation of Iceland. Clim Chang 147(3-4):369-381

Sigl M, Winstrup M, McConnell JR et al (2015) Timing and climate forcing of volcanic eruptions for the past 2,500 years. Nature 523:543-549. https://doi.org/10.1038/nature14565

Stoffel M, Khodri M, Corona C, Guillet S, Poulain V, Bekki S, Guiot J, Luckman BH, Oppenheimer C, Lebas N, Beniston M, MassonDelmotte V (2015) Estimates of volcanic-induced cooling in the Northern Hemisphere over the past 1,500 years. Nat Geosci 8(10):784-788

Stothers RB (1998) Far reach of the tenth century Eldgjá eruption, Iceland. Clim Chang 39:715-726

Vinther BM, Clausen HB, Johnsen SJ, Rasmussen SO, Andersen KK, Buchardt SL, Dahl-Jensen D, Seierstad IK, Siggaard-Andersen ML, Steffensen JP, Svensson A, Olsen J, Heinemeier J (2006) A synchronized dating of three Greenland ice cores throughout the Holocene. J Geophys Res 111:D13102. https://doi.org/10.1029/ 2005JD006921

Zielinski GA, Germani MS, Larsen G, Baille MGL, Whitlow S, Twickler MS, Taylor K (1995) Evidence of the Eldgjá (Iceland) eruption in the GISP2 Greenland ice core: relationship to eruption processes and climatic conditions in the tenth century. Holocene 5:129-140 